\section{Tverrfaglig om nevromuskulære sykdommer}

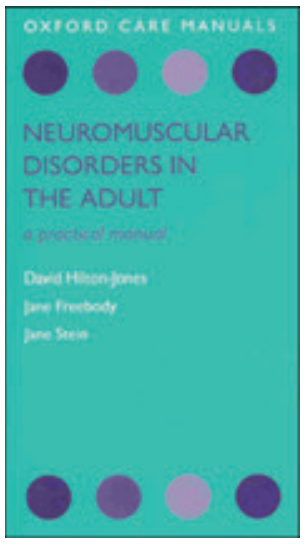

David Hilton-Jones, Jane Freebody,

Jane Stein

Neuromuscular disorders in the adult

A practical manual. 200 s, tab, ill. Oxford:

Oxford University Press, 2011. Pris GBP 22

ISBN 978-0-19-958035-4

Forfatterne har lang erfaring i multidisiplinært arbeid med voksne som lider av nevromuskulære sykdommer. Klinikere er målgruppen, men åpenbart også fagpersoner med annen utdanningsbakgrunn enn legene (fysioterapeut, sykepleier, ergoterapeut og andre) og som i større eller mindre grad arbeider med denne pasientgruppen. Denne lille boken kan man ha i frakkelommen eller i innerlommen på en jakke. Den er oversiktlig og det er plass til notater, men bildematerialet er av noe varierende kvalitet.

Innholdet dekker voksne med nevromuskulær sykdom, inklusive sykdommer som har debutert i barndommen (som Duchennes muskeldystrofi) og ellers arvelige muskelsykdommer som fører til progredierende muskelsvakhet, spinal muskelatrofi samt inklusjonslegememyositt. Også arvelig nevropati (Charcot-Marie-Tooths sykdom) nevnes kort. Andre sykdommer som motornevronsykdom (ALS), andre inflammatoriske myopatier og myasthenia gravis omtales ikke.

Beskrivelsen av de aktuelle sykdommene i første kapittel, Hva er nevromuskulcere sykdommer, er kortfattet og omfatter bare hovedtrekk. Det hadde imidlertid vært ønskelig med litt data om f.eks. aktuelle kjente mutasjoner ved de omtalte sykdommene, og plass hadde det vært selv i en slik liten håndbok. Forfatterne tar for seg ulike behandlingstilnærminger, men her kunne godt omtalen av genetikken ha vært flyttet til slutten av første kapittel om sykdomsbeskrivelse. I annet kapittel refereres det innledningsvis til sykdomsspesifikke protokoller, hvorav noen finnes i et appendiks på slutten av kapitlet. For øvrig gis det korte, nyttige oversikter over relevant monitorering og behandling av lunge- og hjertefunksjoner, tale- og svelgeproblemer, ortopedisk intervensjon, forhold under svangerskap og medikamentell behandling, der dette er en aktuell mulighet.

Aspekter ved det å være innlagt i sykehus omtales, f.eks. innleggelse etter beinbrudd. Det pekes på at det ofte vil være behov for spesiell tilrettelegging for den muskelsvake pasient. Særskilte operative inngrep, som scapulafiksasjon hos pasienter med facioskapulær muskeldystrofi, nevnes også.

Hjelpemidler for gangfunksjon, ulike ortoser og rullestoler beskrives og illustreres. Ikke minst legges det vekt på råd og tiltak for god livskvalitet både fysisk og psykologisk.

I sluttkapitlet, Å leve med muskelsykdom, tar man for seg aktuelle hjelpemidler, støttepersoner, seksualliv og svangerskap, det å dele informasjon med andre samt spørsmål omkring økonomi og rettigheter for pasienter i denne sykdomsgruppen.

Naturlig nok er en del av informasjonen spesifikk for forhold i Storbritannia, men Neuromuscular disorders in the adult er absolutt leseverdig og kan brukes til å slå opp i. Styrken er den tverrfaglige tilnærmingen fra fagpersoner med lang erfaring på feltet. Den legger et godt grunnlag for, og peker på muligheter til god samhandling for denne pasientgruppen.

\section{God og lettlest bok om schizofreni}

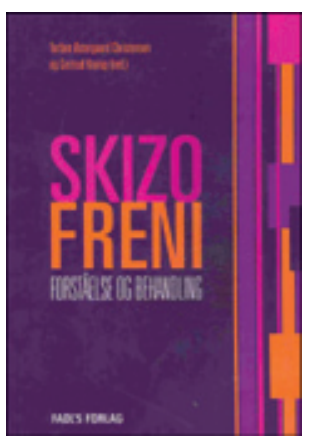

\author{
Torben Østergaard Christensen, \\ Gertrud Krarup, red. \\ Skizofreni \\ Forståelse og behandling. 193 s, tab, ill. \\ København: FADL's Forlag, 2011. \\ Pris DKK 300 \\ ISBN 978-87-7749-501-4
}

Her er schizofreni fremstilt som en komplisert psykisk sykdom, men forfatterne klarer å skildre dette på en måte som er lett å følge. Skizofreni er inndelt i 13 kapitler. Det første er skrevet av en 30-årig kvinne som har hatt sykdommen i fem år, de øvrige av danske psykologer og psykiatere, vesentlig fra Århus.

Forfatterne henvender seg til alle behandlere som arbeider med pasienter som har sykdommen i ulike faser, men den er skrevet slik at også studenter, pasienter og pårørende kan ha nytte av den. Her gis et historisk tilbakeblikk og beskrivelser av relevante forhold knyttet til diagnostikk, årsaksforhold, forløp, prognose, nevrobiologi, komorbiditet, utredning og behandling.

Fremstillingen er balansert, og relativt mye plass er viet behandlingsmulighetene og det empiriske grunnlaget for disse. Samspillet mellom de biologiske, de psykologiske og de sosiale behandlingselementene kommer godt frem. Boken er tiltenkt et dansk publikum, og tilretteleggingen er preget av dette når det gjelder fremstilling av tradisjoner, behandlingsopplegg, lovgivning og henvisning til litteratur. Med dette forbehold kan den imidlertid trygt anbefales et tilsvarende norsk publikum. Den er spesielt egnet for oppdatering for klinikere - både leger, psykologer og sykepleiere, men også andre profesjoner som inngår i de tverrfaglige behandlingsmiljøene.

\section{Stein Opjordsmoen Ilner}

Klinikk psykisk helse og avhengighet

Oslo universitetssykehus, Ullevål 